\title{
Research on Management in Teaching Evaluation
}

\author{
Jingde Huang*
}

\author{
Zhuhai College of Science and Technology, Zhuhai, China \\ *Corresponding author.Email: jdh925@sina.com
}

\begin{abstract}
The purpose of teaching evaluation in colleges and universities is to standardize teaching and improve the level of talent training. Scientific teaching evaluation is not only a comprehensive test of the strength of colleges and universities, but also a comprehensive display of the atmosphere of colleges and universities and the mental outlook of teachers and students. As the grass-roots unit to implement the evaluation requirements of the superior, the professional department is responsible for implementing the contents and requirements of teaching evaluation. By building a first-class teaching team, first-class majors and first-class courses, we can improve the popularity of the major in the industry and meet the social requirements. Focusing on the focus of teaching evaluation, this paper puts forward the problems existing in the specialty according to the evaluation scheme, further deepen the teaching reform, and make the front-line teaching work truly reach the high-quality level.
\end{abstract}

Keywords: Teaching evaluation, Evaluation programme, Specialty construction, Teaching resources

\section{THE IMPORTANT POSITION OF TEACHING EVALUATION}

In the process of meeting the undergraduate teaching evaluation, giving priority to the undergraduate teaching evaluation of professional departments can fully avoid the tendency of professional departments to ignore quality and emphasize efficiency ${ }^{[1-3]}$. Colleges and universities can take the undergraduate teaching evaluation of professional departments as one of the ways for colleges and universities to regulate the school running level of professional departments, and the evaluation results can be used as an important basis for the training of teachers and the allocation of teaching resources ${ }^{[4-5]}$. The evaluation shall be carried out by professional departments and assessed by the expert group of the Institute. In order to enable the evaluation of professional departments to be carried out smoothly, according to the evaluation requirements of the Ministry of Education, the evaluation office of colleges and universities uniformly puts forward the distinctive evaluation methods and basic requirements of undergraduate teaching work of professional departments, and puts forward the work suggestions of the expert group on undergraduate teaching evaluation of professional departments, and designs the supporting forms that centrally reflect the undergraduate teaching work of professional departments in cooperation with the evaluation index system. Establishing a long-term educational concept and establishing a characteristic undergraduate teaching evaluation system is not only beneficial to the current teaching evaluation, but also can be used as a permanent institutional measure, which can not only lay a good foundation for undergraduate teaching evaluation, but also provide a long-term effective control means for undergraduate teaching quality in colleges and universities from a long-term perspective.

\section{KEY POINTS OF TEACHING EVALUATION}

\subsection{Formulating evaluation plan}

According to the evaluation requirements, combined with the actual teaching work of various majors in colleges and universities, formulate a practical and feasible evaluation scheme of professional departments ${ }^{[6-7]}$. On the basis of extensive investigation and discussion, in accordance with the guiding ideology of the Ministry of Education, strengthen the macro management of the teaching work of various professional departments in colleges and universities, urge the leaders of professional departments to pay attention to undergraduate teaching, promote teaching reform and teaching capital construction, formulate distinctive professional department based teaching 
evaluation schemes, and constantly improve the school running level and teaching quality.

\subsection{Adhere to the guiding ideology of the combination of evaluation and construction}

Professional departments are required to take the evaluation scheme as the reference frame, treat the evaluation work with a positive attitude, and carry out self-evaluation seriously; summarize the work realistically, dare to find problems and gaps; make every effort to take various measures to honestly solve the existing problems and do a solid job in various work; deepen the teaching reform with innovative spirit and action, and create the school running characteristics of each department. In the process of teaching evaluation of professional departments in colleges and universities, it is advisable to put forward general requirements. We should not be overly optimistic or pessimistic about the evaluation results, nor be indifferent to the evaluation results. We should seriously study and solve the problems and shortcomings found in the evaluation, and strive to meet the evaluation of the undergraduate evaluation group with excellent results.

\subsection{Starting the undergraduate teaching evaluation of professional departments}

According to the teaching evaluation requirements and the focus of teaching work in colleges and universities, and according to the teaching task requirements of each semester, revise the undergraduate teaching evaluation scheme of professional departments. At the end of each semester, the notice on the evaluation of undergraduate teaching work of professional departments and the evaluation scheme will be issued in the next semester. Finally, the next stage of evaluation of the professional department shall be carried out according to the time and evaluation procedures specified in the notice.

\section{THOUGHTS AND COUNTERMEASURES OF TEACHING EVALUATION}

Change ideas, emphasize the evaluation of professional departments to serve the evaluation of colleges and universities, and pay attention to formative evaluation ${ }^{[8-9]}$. That is, it emphasizes the transformation from paying attention to the evaluation conclusion to the evaluation process, paying attention to the process to ensure the results, helping colleges and universities judge the problems existing in the teaching process of each specialty through the evaluation of professional departments, and helping to solve them. At the same time, strengthen the inspection on the rectification and effect of existing problems.

\subsection{Encouraging and improving teachers' academic and teaching level}

In order to meet the first round inspection requirements of teaching evaluation and ensure the integrity of documents, the academic affairs office can provide targeted guidance to teachers. The expert group will be set up in advance. New teachers must pass the acceptance of the expert group before they can take up their posts. The specific acceptance method can be 10 courses designated by the new teacher, and the content can be temporarily extracted by the expert group for trial teaching. At the same time, professional departments are required to back up the qualification certificates of new teachers.

Teachers are in the forefront of undergraduate teaching. To welcome evaluation and create excellence, we must stimulate the enthusiasm of teachers in the whole college. This must give priority to encouraging and invigorating the teaching atmosphere from the policy. At present, the teacher performance appraisal mechanism of some colleges and universities in China is not scientific enough. The academic affairs office and the personnel office can take the lead in formulating the assessment methods for professional and technical teachers in colleges and universities, and conduct performance assessment according to the performance score from the aspects of teaching, scientific research, discipline construction, laboratory construction, teaching research, academic research, counseling and Q $\&$ A, guiding papers, teaching management and so on, It also fully reflects the process of self-evaluation and being evaluated. Colleges and universities set the evaluation proportion, and the evaluation results are archived as excellent results, which can be used as the basis for meritorious service, award and evaluation of excellent teachers, so as to truly commend and respect teachers with excellent performance and stimulate their work enthusiasm. The specific process: first, the teacher should make a self-assessment according to the regulations; the second step is that the self-rated winners are examined and approved by the professional department; The third step is to assess excellent teachers. After the evaluation and decision of all teachers in the unit, the winners will be selected from the excellent teachers, that is, they will be rewarded with reason and merit; at the same time, the excellent results of teacher assessment shall be archived.

Strictly implement the teaching discipline, check the teachers' implementation of teaching discipline through regular and irregular teaching inspection and various teaching information feedback channels, and deal with it in time according to the identification and handling methods of teaching accidents. At the same time, teachers are encouraged to actively undertake scientific research and write high-quality research papers; support teachers to actively participate in teaching research, 
especially the reform of teaching contents and methods, and constantly improve their academic level and professional ability.

Encouraging and supporting teachers to carry out teaching research, compile and publish teaching materials. Encourage backbone teachers with high teaching level and strong scientific research ability to actively participate in the front line of teaching, regularly carry out selection activities for young and middle-aged backbone teachers, discipline and academic leaders, and promote the construction of discipline team and innovation team; Regularly carry out activities such as basic teaching skills competition for young teachers.

\subsection{Optimizing the construction of course materials and teaching hardware}

According to the professional knowledge module, practical ability training module, comprehensive quality training module and personality development training module in the current teaching plan, the curriculum construction system is planned as a whole, and the curriculum construction tasks are fully implemented by disciplines and majors. All undergraduate courses offered by colleges and universities are in terms of teaching material selection, teaching assessment, teaching effect, etc, check whether it meets the curriculum standards of undergraduate teaching and become a qualified curriculum.

Facing the professional curriculum group, strengthen the task of curriculum construction to form a supporting curriculum system. Each professional department under the overall planning of curriculum construction in colleges and universities, according to their own reality, establish a project for the construction of college level key courses and formulate corresponding curriculum construction plans; establish a curriculum construction leader system, and the curriculum leader shall formulate the goal plan and annual implementation plan of college level key curriculum construction in a planned and stepby-step manner according to the basic conditions and construction direction of qualified courses and excellent courses promote the construction of college level key courses. Colleges and universities establish effective incentive and evaluation mechanisms to encourage teachers, team leaders and students to actively participate in the construction of high-quality courses and network course teaching. Colleges and universities implement the combination of goal and process management for key courses, carry out dynamic management, and implement the annual inspection system for key courses.

Increase the support and investment in the construction of teaching materials, and actively carry out the construction of applied undergraduate teaching materials in colleges and universities. It is suggested to set up a special fund for textbook construction, strengthen the awareness of cultivating applied talents, carry out textbook construction through project approval based on the achievements of curriculum reform and construction, and compile and publish a series of applied undergraduate textbooks with high quality, distinctive characteristics and strong adaptability. By organizing forces, scientifically summarizing, fully excavating and carefully cultivating projects with obvious application-oriented characteristics and certain advantages, we will focus on supporting the construction of characteristic teaching materials. Establish the awareness of high-quality teaching materials, and continue to adhere to the principle of selecting the best teaching materials on the basis of the original provincial planning teaching materials, so as to ensure that high-quality and characteristic teaching materials enter the classroom and ensure the teaching quality. At the same time, we should also consider the professional characteristics of the teaching materials used in each specialty, such as the engineering drawing teaching materials of engineering design specialty and the mechanical drawing teaching materials of mechanical design specialty. Although the course names are different, but the basic contents are similar, we can consider building a more suitable teaching material system.

Strengthen the construction of digital teaching environment such as teaching website, multimedia network classroom and digital library ${ }^{[10]}$. Regularly carry out network teaching training and competition activities of modern educational technology, encourage teachers to apply modern teaching means, make full use of multimedia software and simulation training equipment developed by colleges and universities, realistically simulate front-line production scenes, and improve teaching level and classroom teaching effect. Establish courseware resource database to realize the sharing of high-quality teaching resources. Build the network teaching platform to broaden the application scope and practical means of network course teaching.

\subsection{Improving students' innovative spirit and practical ability}

In order to ensure the teaching quality of practical teaching and the proportion of experimental projects, the laboratory construction plan must be formulated according to the needs of practical teaching. Ensure that the opening rate of each professional experiment reaches $100 \%$ of the requirements of the syllabus; increase the proportion of comprehensive and practical experiments; strengthen overall planning and management, realize resource sharing and improve utilization efficiency. Teach students according to their aptitude and form an experimental teaching mode 
conducive to the development of students' potential and ability.

Stabilize and enrich the experimental teaching staff to ensure the smooth progress of experimental teaching.

Take effective measures to further improve the quality of graduation project, strictly manage the process of graduation project, strengthen the guidance and review of students' graduation thesis, and establish an inspection and evaluation system.

\subsection{Formulating teaching material construction plan}

According to the teaching material construction plan of colleges and universities, on the basis of organizing the construction of planned teaching materials at all levels, combined with the construction of advantageous disciplines and excellent courses in colleges and universities, focus on the construction of teaching materials for professional courses and compulsory courses for professional development, and review and revise teaching materials such as business leader training, new equipment training, short-term job training and external training, so as to form a three-dimensional teaching material construction; Establish the information feedback system of textbook quality.

\subsection{Formulating the construction plan of digital teaching resources}

Relying on teaching websites, focusing on the digital transformation of existing teaching resources, taking the construction of provincial high-quality courses, key majors and network courses as a breakthrough, give full play to the advantages of computer technology, network technology and multimedia technology teaching, and reflect the important role of teaching websites in this science and education, build a digital teaching center that can not only meet the needs of students' professional knowledge, but also expand students' quality education, and create network digital teaching resources conducive to students' quality education and skill training. Start the construction of three-dimensional teaching resources of key construction courses, highquality construction courses, professional compulsory courses and experimental teaching center, and build a video course resource library with teaching demonstration significance, professional characteristics and representative of typical equipment conditions on the basis of the existing network courses.

\section{ANALYSIS ON THE SUPERIORITY OF TEACHING EVALUATION}

The undergraduate teaching evaluation of professional departments can play a vital role in strengthening and improving the macro management and guidance of colleges and universities on the teaching work of professional departments and improving the overall school running level:

Through the top-level design of colleges and universities, the teaching evaluation of professional departments is gradually carried out, and the professional departments further clarify the guiding ideology of running schools of various disciplines, with more accurate positioning and clearer running ideas. Through self inspection and self-evaluation, it is fully reflected in the training plan and daily teaching and management, which increases the teaching power and vitality of the professional department, and the selfregulation ability of the professional department is continuously enhanced. In combination with the actual situation of colleges and universities, each professional department can also put forward, adjust and improve the school running orientation and talent training objectives of colleges and universities.

Further establish the central position of undergraduate teaching and continuously improve the teaching conditions. Colleges and universities can take the opportunity of carrying out undergraduate teaching evaluation of professional departments to set the evaluation index systems such as "number and structure of teachers", "teaching funds" and "teaching infrastructure" as important indicators to guide all units to continuously increase teaching investment and improve school running conditions.

Promoting teaching reform and construction in colleges and universities is an important means of teaching evaluation. Colleges and universities can increase teaching investment by setting up a variety of special funds such as curriculum construction, teaching reform, textbook construction, laboratory construction and characteristic specialty construction, so as to support and encourage teachers to participate in teaching reform and construction. On the other hand, the development of teaching evaluation in professional departments will also increase the urgency and enthusiasm of teaching reform and construction in professional departments. On the one hand, actively organize teachers to participate in the project research of teaching reform and the publication of teaching materials, on the other hand, provide corresponding supporting subsidies and rewards for the construction projects and awards funded by the project, so as to fully mobilize the enthusiasm of teachers to participate in reform, be willing to reform and dare to reform.

By establishing the teaching quality monitoring system, the teaching management can be greatly strengthened and improved, and the level of teaching management can be continuously improved. In the evaluation of professional departments, colleges and universities should not only pay attention to hardware such as teaching investment and teaching conditions, 
but also pay attention to the construction of software, especially teaching management. The annual professional department evaluation is not only a summary and evaluation of the work in the past year, but also a test of the teaching management level of the professional department. Firstly, through the evaluation work, the teaching management documents and systems of professional departments will certainly be continuously improved and implemented more strictly. The three-level responsibility system for teaching work in colleges, universities and professional departments has been strengthened, and the teaching management will gradually move from experience management to scientific, standardized and systematic management. Secondly, it will also promote the collection, sorting and standardized management of teaching materials.

\section{CONCLUSION}

By carrying out professional department evaluation, colleges and universities can systematically grasp the real situation of the teaching level of the whole college, and find the right direction for meeting the undergraduate teaching evaluation. Through the corresponding establishment of distinctive teaching quality monitoring systems in professional departments, it also improves the teaching quality monitoring system in colleges and universities, which can not only provide a strong guarantee for the smooth development of teaching work in colleges and universities and improve teaching quality, but also lay a good foundation for the evaluation of undergraduate teaching level.

\section{ACKNOWLEDGMENTS}

This paper is supported by the teaching quality engineering project of Guangdong Provincial Department of Education and Zhuhai College of Science and Technology.

\section{REFERENCES}

[1] Ning Shan, Analysis and practice from engineering education to engineering culture education, Teaching research, vol. 35, pp.33-34, 2012.

[2] Cheng Shaowei, On network education in the information age, Education and occupation, pp.165-166, 2014.

[3] Li Yunze, Investigation and Research on diversified and open classroom teaching mode of engineering courses in research universities, Teaching research, vol. 34, pp. 41-44, 2011.

[4] Jingde Huang, Xiaomin Li, Research on the method of engineering course training new students based on ideological \& political education,
Education, E-learning and Social Science, pp.4144,2020.

[5] Hui Shuai, Zhang Enguang, Application of UGNX component family in the creation of standard parts in the design of basic courses of manufacturing technology, examination weekly, pp.18-19, 2018.

[6] Huang Jingde, Practice and exploration of machine vision curriculum construction under the background of new engineering, Research on innovative education, vol. 9, (4): 858-864, 2021.

[7] Li Xiaoda, Classic Course Construction of Stamping Process and Die Design, Lecture Note in Management Science, pp.159-163, 2017.

[8] Zhang Xiaosu, $\mathrm{Xu}$ Guoqin, Problems and Countermeasures in professional Modular Teaching, Business information, vol. 52, (2): 171, 2011.

[9] Liu Guoqin, Theory and practice of training applied talents in colleges and universities, Beijing: People's publishing house, pp.32-36, 2007.

[10] Li Wang, Enguang Zhang, Integration of Virtual Manufacturing Technology and Course Teaching of Manufacturing Technology, Humanities and Social Science, pp.191-194, 2017. 